\title{
Resistance to Monopartite Begomoviruses Associated with the Bean Leaf Crumple Disease in Phaseolus vulgaris Controlled by a Single Dominant Gene
}

\author{
Francisco Monci, Susana García-Andrés, José Antonio Maldonado, and Enrique Moriones
}

First, second, and fourth authors: Estación Experimental "La Mayora," Consejo Superior de Investigaciones Científicas, 29750 AlgarroboCosta, Málaga, Spain; and third author: Seminis Vegetable Seeds Iberica, Almería, Spain. Accepted for publication 23 February 2005.

\begin{abstract}
Monci, F., García-Andrés, S., Maldonado, J. A., and Moriones, E. 2005. Resistance to monopartite begomoviruses associated with the bean leaf crumple disease in Phaseolus vulgaris controlled by a single dominant gene. Phytopathology 95:819-826.

Tomato yellow leaf curl virus (TYLCV) and Tomato yellow leaf curl Málaga virus are monopartite begomoviruses (genus Begomovirus, family Geminiviridae) that infect common bean (Phaseolus vulgaris), causing bean leaf crumple disease (BLCD). This disease was found to be widespread in southern Spain and causes stunted growth, flower abortion, and leaf and pod deformation in common bean plants. Commercial yield

characterized a resistance trait to BLCD-associated viruses in the common bean breeding line GG12. This resistance resulted in a complete absence of BLCD symptoms under field conditions or after experimental inoculation. Our analysis showed that virus replication was not inhibited. However, a severe restriction to systemic virus accumulation occurred in resistant plants, suggesting that cell-to-cell or long-distance movement were impaired. In addition, recovery from virus infection was observed in resistant plants. The reaction of $P$. vulgaris lines GG12 (resistant) and GG14 (susceptible), and of $\mathrm{F}_{1}, \mathrm{~F}_{2}$, and backcross populations derived from them, to TYLCV inoculation suggested that a single dominant gene conferred the BLCD resistance described here.
\end{abstract} losses of up to $100 \%$ occur. In the present study, we have identified and
The family Geminiviridae comprises plant viruses that have a circular, single-stranded DNA genome and distinctive twinned, icosahedral virions. Geminiviruses are classified into four genera based on type of insect vector, host range, and genome organization (51). The genus Begomovirus includes species with monopartite or bipartite genomes that are transmitted by the whitefly Bemisia tabaci Gennadius (Hemiptera: Aleyrodidae). In tropical and subtropical areas, begomoviruses constitute a serious constraint to production of economically important crops $(37,45,52)$. Among begomoviruses, the monopartite Tomato yellow leaf curl virus (TYLCV) causes devastating damage to tomato (Lycopersicon esculentum Mill.) crops in numerous countries $(38,44)$. In addition, TYLCV was found to be a severe pathogen of common bean (Phaseolus vulgaris L.) for fresh produce markets (40). TYLCV causes the bean leaf crumple disease (BLCD) in common bean, manifested as stunted plant growth, abnormal shoot proliferation, reduction of internodes, thickening and crumpling of infected leaves, flower abortion, and pod deformation. BLCD outbreaks can result in commercial yield losses of up to $100 \%$ (40). Infection of TYLCV in common bean crops also has been reported in the Caribbean region $(33,53)$. Recent studies indicated that the BLCD also could be associated with another monopartite begomovirus, Tomato yellow leaf curl Málaga virus (TYLCMalV). TYLCMalV is a natural recombinant derived from a genetic exchange between TYLCV and Tomato yellow leaf curl Sardinia virus (TYLCSV) (35), the latter being a distinct Begomovirus sp. that infects tomato but not common bean $(43,55)$.

Control of begomoviruses is difficult and relies on intensive use of insecticides to manage vector populations. However, the use of

Corresponding author: E. Moriones; E-mail address: moriones@eelm.csic.es

DOI: 10.1094/PHYTO-95-0819

(C) 2005 The American Phytopathological Society chemicals is only partially effective, and this practice damages the environment and can result in pesticide-resistant Bemisia tabaci $(7,8,15,44)$. Therefore, as for other plant viruses $(24,30,47)$, utilization of natural resistance traits is the most desirable means of control. Much work has been done in searching for sources of begomovirus resistance, and resistance traits have been found that can affect viral replication and local or systemic movement within plants $(24,27,36,44)$. Moreover, begomoviruses can trigger gene silencing $(10,11,32,39)$, a natural antiviral defense mechanism in plants $(4,64,67,69)$. Gene silencing may prevent virus accumulation in new leaves, thus leading to recovery.

In $P$. vulgaris, resistance to bipartite begomoviruses has been reported $(27,36,60)$. We have found two breeding lines, GG9 and GG12 (Seminis Vegetable Seeds Iberica, Almería, Spain), that exhibit resistance to BLCD (E. Moriones, F. Monci, and J. A. Maldonado, unpublished data). The objectives of this study were to (i) evaluate the incidence of BLCD in affected areas of southern Spain, (ii) confirm the resistance of GG9 and GG12 under conditions of natural infection or experimental infection using TYLCV and TYLCMalV, and (iii) determine inheritance of BLCD resistance in the common bean line GG12.

\section{MATERIALS AND METHODS}

General methods. Standard manipulations of nucleic acids and bacteria were performed according to protocols in Sambrook et al. (54).

Field surveys. The incidence of BLCD was examined in the major regions of Spain that produce common bean for fresh market (flat pod snap-type pole green beans). Surveys were conducted in Almería and Málaga (south coast) during 1999 to 2003. Commercial fields were visited randomly, and in each field the percentage of BLCD-affected plants was estimated. A number of BLCD-symptomatic plants also were sampled (one young leaf 
per plant) from each field. BLCD was associated in Spain only with TYLCV- or TYLCMalV-like monopartite begomoviruses (E. Moriones, unpublished data); therefore, the samples collected were analyzed by hybridization of tissue blots from leaf petiole cross sections, using probes to these viruses (described below).

Virus clones. The infectious clone of an isolate of the type strain of TYLCV from southern Spain, TYLCV-[Alm], was provided by E. R. Bejarano, Málaga University, Spain. The construction of an infectious clone of an isolate of the Mld strain of TYLCV, TYLCV-Mld[ES7297], has been described (40). The Mld strain differs genetically from the TYLCV type strain (41) and, on some tomato cultivars, causes symptoms that are significantly milder than those induced by the native virus (2). The construction of infectious clones of TYLCSV-ES[1] and TYLCMalV[ES42199] has been described $(35,43)$.

Plant materials. GG9 and GG12 (Seminis Vegetable Seeds Iberica) are common bean breeding lines that exhibited resistance to BLCD in a preliminary field trial (data not shown); the former is of Andean origin, whereas the latter is of Middle American origin (59). GG5 and GG14 (Seminis Vegetable Seeds Iberica) are Andean type (59) common bean breeding lines susceptible to the BLCD. All four breeding lines are snap-type beans. To study inheritance of BLCD resistance found in GG12, a series of crosses were made by hand pollination between GG12 and the BLCDsusceptible GG14 line and their progeny. Plant lines, including the two parents, the $\mathrm{F}_{1}$ hybrid $(\mathrm{GG} 12 \times \mathrm{GG} 14)$, the corresponding $\mathrm{F}_{2}$ progeny, and progeny from the first backcross to the resistant $\left(\mathrm{F}_{1} \times \mathrm{GG} 12, \mathrm{BC}_{1 \mathrm{R}}\right)$ and to the susceptible $\left(\mathrm{F}_{1} \times \mathrm{GG} 14, \mathrm{BC}_{1 \mathrm{~S}}\right)$ parents, were used in the genetic studies.

Virus inoculation. Inoculation via the whitefly vector (natural inoculation) was performed in a commercial plastichouse located at El Ejido (Almería, southern Spain) under the high-BLCD-pressure conditions normally present during late summer and early autumn. Two to four replications with $\approx 10$ test plants per replication were located randomly in the plastichouse. Experiments were performed twice, during 2001 and 2002. Experimental inoculations were performed by means of Agrobacterium tumefaciensmediated inoculation (hereafter referred to as agroinoculation) as described by Monci et al. (35) using infectious clones of either TYLCSV, TYLCMalV, or the type and Mld strains of TYLCV (described previously). Common bean plants (first-trifoliolate-leaf growth stage) were agroinoculated using a stem puncture method. Briefly, $\approx 20 \mu \mathrm{l}$ of A. tumefaciens culture was expelled from a 1-ml syringe with a 27-gauge needle into puncture wounds made in the stem. For virus invasion studies, a leaf-inoculation method was used with $\approx 40 \mu \mathrm{l}$ of bacterial culture deposited on three wounds ( $2 \mathrm{~cm}$ long) made with a razor blade within one leaflet of the first trifoliolate leaf of each plant. After agroinoculation, plants were maintained in a growth chamber $\left(25^{\circ} \mathrm{C}\right.$ during the day and $20^{\circ} \mathrm{C}$ at night, $70 \%$ relative humidity, with a 16 -h photoperiod at $250 \mu \mathrm{mol} \mathrm{s}^{-1} \mathrm{~m}^{-2}$ photosynthetically active radiation) or in an insect-free glasshouse $\left(\approx 16-\mathrm{h}\right.$ day at $24^{\circ} \mathrm{C}$ and $18^{\circ} \mathrm{C}$ at night, with light supplementation as needed) until analyzed. Inoculation controls were plants of the susceptible common bean lines GG5, GG14, or both, or of the susceptible tomato cv. Moneymaker (agroinoculated at the three-leaf growth stage).

Analysis of virus movement. Virus invasion of common bean plants was monitored under growth chamber conditions after leafagroinoculation with TYLCV-Mld[ES7297]. Groups of three plants of GG12 and GG14 were analyzed at 3, 7, 15, and 40 days postinoculation (dpi). At $3 \mathrm{dpi}$, presence of viral forms in the inoculated region of each plant was examined by Southern blot hybridization analysis of DNA (described below) extracted from pooled 3-mm-wide tissue strips excised from the three inoculated wounds. Geminiviral DNA forms were not detected by Southern blot hybridization analysis in extracts prepared from inoculated tissues at the 0 day time point (data not shown). Therefore, the detection of geminiviral DNA forms at $3 \mathrm{dpi}$ is indicative of repli- cation in the plant cells and not in A. tumefaciens cells (57). At 7, 15 , and $40 \mathrm{dpi}$, presence of virus in different plant organs was examined by dot blot hybridization and polymerase chain reaction (PCR) analysis. DNA extracts were obtained from tissue samples collected from the inoculated area, between the inoculated area and the leaf petiole, from the petiole of the inoculated leaf, and from the newly emerging leaf (locations 1 to 4, respectively). At $40 \mathrm{dpi}$, the inoculated trifoliolate leaf was senescent in most plants, and tissues from locations 1 to 3 could be analyzed from only one plant of each genotype. Negative controls were from samples of GG14 plants agroinoculated with TYLCSV or mock inoculated with a culture of $A$. tumefaciens containing the binary cloning vector $\mathrm{pBin} 19$ (5).

Preparation of plant DNA and hybridization analysis. $\mathrm{Nu}$ cleic acids were extracted from plant samples essentially as described by Accotto et al. (1), and then were treated for $20 \mathrm{~min}$ at $37^{\circ} \mathrm{C}$ with RNAse A (Roche Diagnostics, Mannheim, Germany) at $100 \mu \mathrm{g} / \mathrm{ml}$; DNA was ethanol precipitated, washed with $70 \%$ ethanol, dried, and resuspended in $25 \mu \mathrm{l}$ of Tris-EDTA buffer. DNA preparations were equilibrated for equal loading by dot blot hybridization analysis of dilutions, using a digoxigenin-labeled DNA probe to detect plant DNA corresponding to the $18 \mathrm{~S}$ ribosomal RNA gene (55), which served as an internal standard for total plant genomic DNA. Extracts from healthy tomato or common bean plants were used as negative controls. Positive controls were from tomato plants experimentally infected with TYLCSVES[1] or TYLCV-Mld[ES7297].

Blots were performed on positively charged nylon membranes (Roche Diagnostics). For Southern blot hybridization analysis, DNA ( $5 \mu$ per sample) was fractionated in $1 \%$ agarose gels in Tris-borate-EDTA buffer containing ethidium bromide at $0.5 \mu \mathrm{g} / \mathrm{ml}$ to facilitate separation of the single-stranded (ss) and doublestranded (ds)DNA viral DNA forms, and then transferred to membranes. For dot bots, 1 and $0.5 \mu$ of the DNA preparation of each sample were placed on the membranes. Hybridization of Southern blots, dot blots, or tissue blots was performed according to Sánchez-Campos et al. (55) with a mixture of digoxigenin-labeled DNA probes able to recognize TYLCV, TYLCMalV, and TYLCSV (35).

PCR amplification of viral DNA. PCR conditions used to amplify DNA fragments of TYLCV-Mld[ES7297] have been described (35). Amplification was performed on DNA preparations (0.5 $\mu \mathrm{l}$ per sample) using the primer pair MA-30/MA-31, that amplifies a fragment covering the intergenic region (40). PCRamplified DNA fragments were visualized by electrophoresis in $1 \%$ agarose gels in Tris-acetate-EDTA buffer.

Small RNA detection. TYLCV-specific small RNAs were detected by Northern blotting (20) using $30 \mu \mathrm{g}$ of total RNA obtained from plant tissues (42). Newly developed young leaves were sampled at 7, 14, and 21 dpi from groups of three plants of GG12 and GG14 leaf agroinoculated with TYLCV-Mld[ES7297]. For detection, digoxigenin-labeled complementary sense RNA probes to the full-length genome of TYLCV-Mld[ES7297] were prepared by in vitro transcription from pSP72/97 plasmid (40) with the labeled RNA probe hydrolyzed to lengths averaging 75 nucleotides (13).

Inheritance data analysis. Estimation of the number of loci involved in the inheritance of resistance in the GG12 $\times$ GG14 genetic family were made by $\chi^{2}$ testing of departure from expected resistant:susceptible ratios for different genetic models. Statistical analyses were performed using the statistical software SPSS for Windows (release 11.0.1; SPSS Inc., Chicago).

\section{RESULTS}

BLCD is widespread in southern Spain. Random visits to common bean commercial fields throughout the BLCD-affected areas of the Málaga and Almería provinces in southern Spain 
during 1999 to 2003 revealed that diseased plants frequently were present (Table 1). In those areas, large-seeded snap bean cultivars, probably of Andean origin (59), are grown. Disease incidences of up to $100 \%$ were observed and severe yield losses occurred, especially in fields in which plants were infected during the early growth stages. As expected from previous studies $(35,40)$, analysis of plants indicated a close relationship between the presence of BLCD symptoms and detection of viruses associated with this disease (Table 1). However, there were a few samples that tested negative despite being considered symptomatic during the survey. Although this was not further investigated, the presence of abiotic disorders or infection by potyviruses (genus Potyvirus, family Potyviridae), Southern bean mosaic virus (genus Sobemovirus) (66), or a new crinivirus (genus Crinivirus, family Clostero-

TABLE 1. Incidence of bean leaf crumple disease (BLCD) in fresh-market common bean (Phaseolus vulgaris) commercial crops of Almería and Málaga (southern Spain) during 1999 to 2003

\begin{tabular}{lccc}
\hline Region, year & No. of fields visited & BLCD $(\%)^{\mathrm{a}}$ & Positive/total $^{\mathrm{b}}$ \\
\hline Almería & & & \\
1999 & 5 & 35.6 & $53 / 57$ \\
2000 & 4 & 77.1 & $87 / 95$ \\
2001 & 5 & 32.8 & $66 / 71$ \\
2003 & 3 & 66.6 & $50 / 53$ \\
Málaga & & & \\
1999 & 5 & 80.5 & $120 / 129$ \\
2002 & 5 & 38.8 & $53 / 53$ \\
2003 & 5 & 54.4 & $62 / 70$ \\
\hline
\end{tabular}

a Average incidence of BLCD-symptomatic plants in the fields visited deduced from examination of 50 common bean plants per field, randomly selected following a W-shaped sampling protocol (31).

${ }^{\mathrm{b}}$ Number of positive samples/total number of symptomatic samples collected. Petiole cross sections of BLCD symptomatic samples collected $\approx \approx 10$ to 25 samples per field) were printed on positively charged nylon membranes and hybridized with a probe able to detect Tomato yellow leaf curl virus and Tomato yellow leaf curl Málaga virus $(35,40)$.

TABLE 2. Susceptibility of Phaseolus vulgaris breeding lines to the bean leaf crumple disease (BLCD) under field conditions

\begin{tabular}{|c|c|c|c|c|}
\hline \multirow[b]{3}{*}{ Line, replicate ${ }^{\mathrm{a}}$} & \multicolumn{4}{|c|}{ No. of symptomatic or infected plants/total plants tested } \\
\hline & \multicolumn{2}{|c|}{2001} & \multicolumn{2}{|c|}{2002} \\
\hline & Symptomatic & Infected & Symptomatic & Infected \\
\hline \multicolumn{5}{|l|}{ GG12 } \\
\hline 1 & $0 / 4$ & $0 / 4$ & $0 / 10$ & $0 / 10$ \\
\hline 2 & $0 / 10$ & $0 / 10$ & $0 / 10$ & $0 / 10$ \\
\hline 3 & $0 / 4$ & $0 / 4$ & $0 / 9$ & $0 / 9$ \\
\hline 4 & $0 / 10$ & $0 / 10$ & $0 / 10$ & $0 / 10$ \\
\hline \multicolumn{5}{|l|}{ GG9 } \\
\hline 1 & $0 / 10$ & $0 / 10$ & $0 / 10$ & $0 / 10$ \\
\hline \multirow{2}{*}{\multicolumn{5}{|c|}{ GG5 }} \\
\hline & & & & \\
\hline 1 & $10 / 10$ & $10 / 10$ & $9 / 10$ & $10 / 10$ \\
\hline 2 & $9 / 10$ & $10 / 10$ & $10 / 10$ & $10 / 10$ \\
\hline 3 & $9 / 10$ & $10 / 10$ & $\ldots$ & $\ldots$ \\
\hline 4 & $10 / 10$ & $10 / 10$ & $\ldots$ & $\ldots$ \\
\hline \multicolumn{5}{|l|}{ GG14 } \\
\hline 1 & $6 / 8$ & $6 / 8$ & 7/9 & 7/9 \\
\hline 2 & $8 / 10$ & $8 / 10$ & $8 / 9$ & 9/9 \\
\hline 3 & $\ldots$ & $\ldots$ & $9 / 10$ & $9 / 10$ \\
\hline 4 & $\ldots$ & $\ldots$ & $9 / 10$ & $9 / 10$ \\
\hline
\end{tabular}

${ }^{a}$ Common bean breeding lines GG9 and GG12 and the BLCD-susceptible control lines GG5 and GG14 were tested under field conditions, in assays performed in Almería (southern Spain) during 2001 and 2002.

${ }^{b}$ Number of BLCD-symptomatic or infected plants/total plants tested. Symptomatic: presence of BLCD symptoms on tested plants was monitored 45 days after transplant. Infected: plants were analyzed 45 days after transplant by hybridization of tissue blots of petiole cross sections of young leaves performed on positively-charged nylon membranes. For detection, a probe able to recognize Tomato yellow leaf curl virus and Tomato yellow leaf curl Málaga virus $(35,40)$ was used. viridae) recently found widespread in this area (56) may cause similar symptoms.

The common bean breeding lines GG9 and GG12 exhibited resistance to BLCD. The $P$. vulgaris breeding lines GG9 and GG12 exhibited resistance to BLCD in preliminary field screening. These two lines were tested further during two growing seasons under field conditions in which severe outbreaks of BLCD occurred. No plants of these two genotypes exhibited BLCD symptoms. In contrast, heavy infections occurred in the susceptible control plants of lines GG5 and GG14 (Table 2). A good correlation was found between presence of symptoms and detection of BLCD-associated viruses (Table 2).

When plants were inoculated experimentally, equivalent results were obtained. No GG9 and GG12 plants exhibited BLCD symptoms when inoculated with TYLCV-Mld or TYLCMalV. However, under experimental conditions, some GG9 plants tested positive for TYLCV-Mld (Table 3). GG12 exhibited complete resistance to the type strain of TYLCV (Table 3). Under experimental conditions, most of the susceptible control plants were infected and developed characteristic BLCD symptoms $\approx 15$ dpi, with either TYLCV strain or TYLCMalV (Table 3; data not shown). Symptom severity increased over time in susceptible plants, with no recovery from symptoms observed in the period examined (up to $60 \mathrm{dpi}$ ). As expected from our previous results (35), symptoms were not observed nor was virus detected in any of the common bean plants inoculated with TYLCSV (Table 3). Tomato plants inoculated as controls were infected readily with either virus (data not shown). Based on these results, further resistance studies were conducted using line GG12. Equivalent responses were exhibited by GG12 plants inoculated with both strains of TYLCV or with TYLCMalV; therefore, the Mld strain of TYLCV subsequently was used exclusively.

TYLCV systemic spread is restricted in GG12 common bean plants. Equivalent results were obtained in two repeated

TABLE 3. Susceptibility of Phaseolus vulgaris breeding lines after experimental inoculation with Tomato yellow leaf curl Sardinia virus (TYLCSV), with the type or Mld strains of Tomato yellow leaf curl virus (TYLCV and TYLCV-Mld, respectively), or with Tomato yellow leaf curl Málaga virus $\left(\right.$ TYLCMalV) ${ }^{\mathrm{a}}$

\begin{tabular}{llccc}
\hline & \multicolumn{4}{c}{ No. of plants infected/no. of plants tested } \\
\cline { 2 - 5 } Line, experiment ${ }^{\mathrm{b}}$ & TYLCSV & TYLCV-Mld & TYLCV & TYLCMalV \\
\hline GG12 & & & & \\
1 & $0 / 10$ & $0 / 10$ & $0 / 10$ & $0 / 5$ \\
2 & $0 / 10$ & $0 / 10$ & $\ldots$ & $0 / 5$ \\
3 & $0 / 5$ & $0 / 5$ & $\ldots$ & $\ldots$ \\
GG9 & & & & \\
1 & $0 / 10$ & $2 / 10$ & $\ldots$ & $0 / 5$ \\
2 & $0 / 10$ & $1 / 10$ & $\ldots$ & $0 / 5$ \\
3 & $0 / 5$ & $0 / 5$ & $\ldots$ & $\ldots$ \\
GG5 & & & & \\
1 & $0 / 10$ & $9 / 10$ & $\ldots$ & $4 / 5$ \\
2 & $0 / 10$ & $10 / 10$ & $\ldots$ & $5 / 5$ \\
3 & $0 / 5$ & $5 / 5$ & $\ldots$ & $\ldots$ \\
GG14 & & & & \\
1 & $0 / 10$ & $8 / 10$ & $10 / 10$ & $4 / 5$ \\
2 & $0 / 10$ & $10 / 10$ & $\ldots$ & $5 / 5$ \\
3 & $0 / 5$ & $4 / 5$ & $\ldots$ & $\ldots$ \\
\hline
\end{tabular}

a Plants were inoculated via Agrobacterium tumefaciens using infectious clones of the isolates TYLCV-[Alm] (provided by E. R. Bejarano, Universidad de Málaga, Spain), TYLCV-Mld[ES7297] (40), TYLCSV-ES[1] (43), and TYLCMalV (35).

${ }^{\mathrm{b}}$ Common bean breeding lines GG9 and GG12 were tested for resistance to bean leaf crumple disease causing viruses, using as susceptible control lines GG5 and/or GG14, in three independent experiments.

${ }^{c}$ Number of plants infected/number of plants tested. Plants were analyzed 40 days after inoculation, by hybridization of tissue blots of petiole cross sections of young leaves performed on positively-charged nylon membranes. For detection, a mixture of probes able to recognize TYLCSV, TYLCV, and TYLCMalV $(35,40)$ was used. 
experiments which are exemplified in Figures 1 to 3. Analysis of DNA obtained from inoculated tissues at 3 dpi revealed the presence of viral forms (Fig. 1) in both the resistant GG12 and the susceptible GG14 genotypes. Moreover, similar levels of viral DNA forms were observed in plants of GG12 and GG14 (Fig. 1, lanes 5 to 7 and 8 to 10 , respectively). Therefore, early stages of TYLCV infection were not impaired in GG12 plants and, at least in the inoculated region, TYLCV behaved similarly in plants of resistant and susceptible lines. Replicative viral DNA forms were

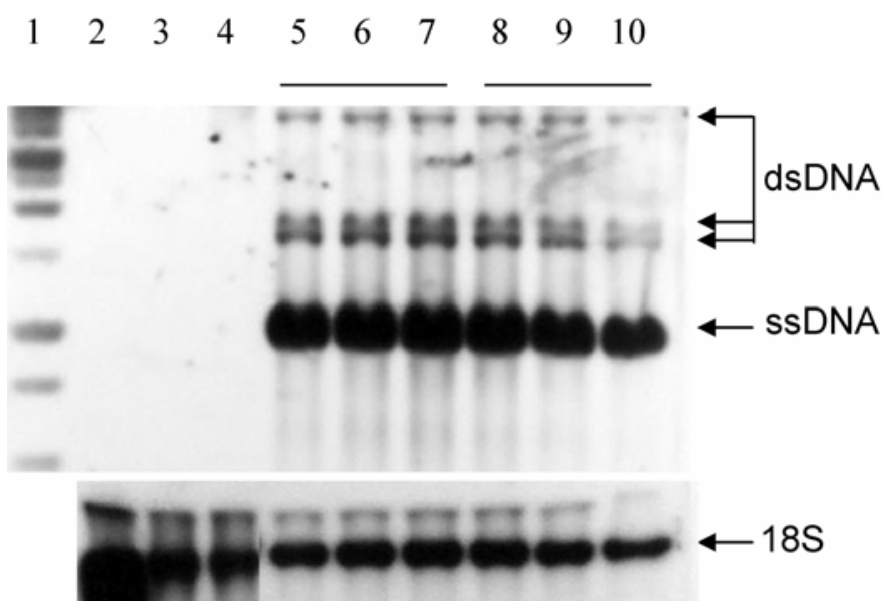

Fig. 1. Southern blot hybridization analysis of DNA extracted from leaf strips collected from the regions of the resistant (GG12) and susceptible (GG14) common bean lines agroinoculated with Tomato yellow leaf curl virus (TYLCV) (lanes 5 to 7 and 8 to 10, respectively) or Tomato yellow leaf curl Sardinia virus (TYLCSV) (lanes 3 and 4, respectively). The membrane was probed with a mixture of DNA probes for TYLCV and TYLCSV (upper panel) or an 18S ribosomal RNA gene (18S) probe (lower panel). Lane 1 contains the 1-kb molecular marker; lane 2 contains DNA extracted from GG14 plants inoculated with Agrobacterium tumefaciens containing the cloning vector free of virus sequences. Positions of replicated viral singlestranded (ss) or double-stranded (ds)DNA forms are indicated on the right of the upper panel. not observed in plants inoculated with a virus-free culture of A. tumefaciens (Fig. 1, lane 2) or with TYLCSV (Fig. 1, lanes 3 and 4).

We next examined virus DNA accumulation profiles in the resistant GG12 and susceptible genotypes inoculated with TYLCV. At 7 and $15 \mathrm{dpi}$, positive hybridization signals were obtained from the inoculated area (Fig. 2B, location 1) of every GG12 and GG14 plant. Virus DNA also was detected in locations outside of the inoculated zone of GG14 plants (evident at $15 \mathrm{dpi}$ ) (Fig. 2B, locations 2 to 4). In contrast, no hybridization signal was obtained from locations 2 to 4 for GG12 plants, except for one plant in which a small amount of virus DNA was detected at location 4 (Fig. 2B, plant 1, 7 dpi). By 40 dpi, striking differences were observed between GG12 and GG14 plants. No viral DNA was detected at any location in GG12 plants, whereas clear hybridization signals were obtained from every location of GG14 plants (Fig. 2B). PCR of the same DNA preparations detected TYLCV in GG14 plants at every location and collection time (Fig. 3). PCR detected viral DNA at every location in GG12 plants at 7 and $15 \mathrm{dpi}$, although less-efficient amplification suggested that, at 15 dpi, less viral DNA was present, especially in locations 2 to 4 . Interestingly, by 40 dpi no viral DNA amplification was obtained for GG12 at any location of every plant tested. Both assays were negative for viral DNA in extracts of mock-inoculated GG12 or GG14 plants (data not shown).

TYLCV-specific small RNAs accumulate in TYLCVresistant and -susceptible common bean plants. To determine whether gene silencing played a role in recovery from TYLCV infection observed in GG12 plants, we studied accumulation of TYLCV-specific small RNAs in inoculated common bean plants (22). Northern blot analyses were performed from samples collected from newly developed young leaves of susceptible and resistant common bean plants on a weekly basis over a period of 3 weeks. In two experiments, equivalent results were obtained (Fig. 4). Low molecular weight RNAs that hybridized with the TYLCV probe were detected at 14 and 21 dpi. Interestingly, small RNAs were detected in both the susceptible GG14 and the resistant GG12 plants inoculated with TYLCV, indicating that this
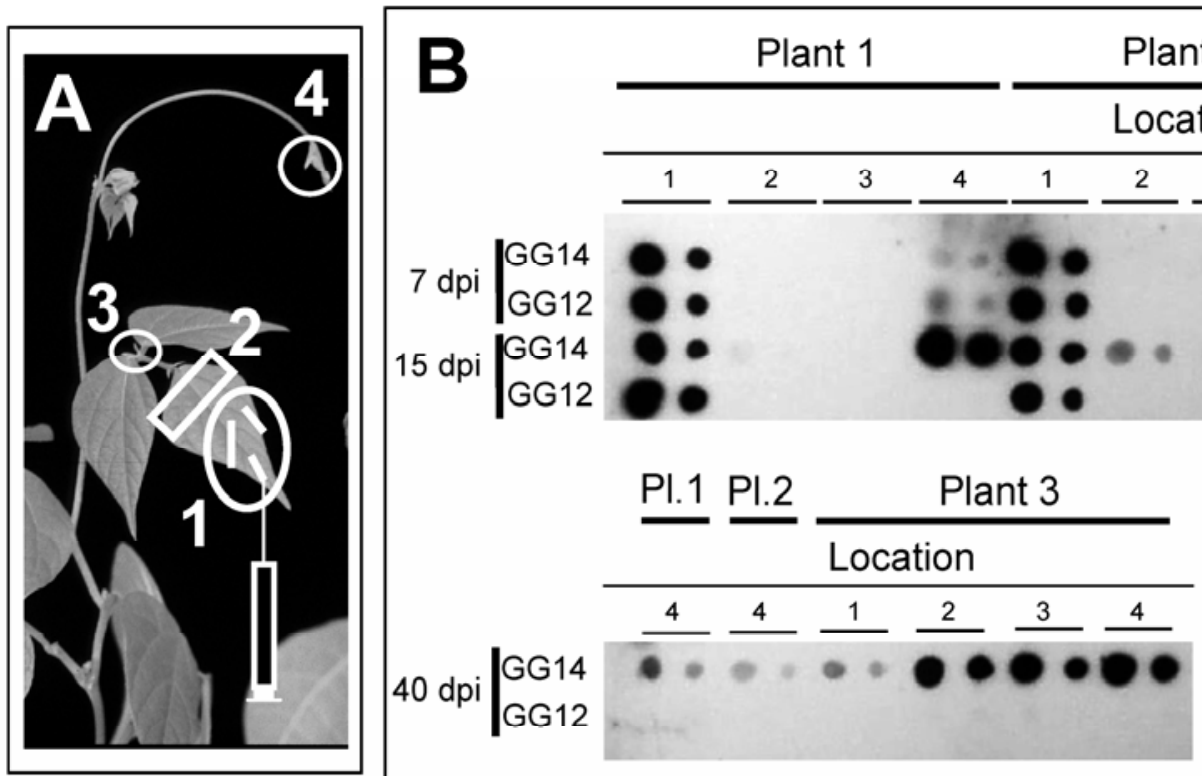

Fig. 2. Dot blot analysis of Tomato yellow leaf curl virus (TYLCV) distribution in Phaseolus vulgaris GG12 and GG14. Plants were agroinoculated with TYLCVMld on wounds made in the expanded blade of one leaflet of the first trifoliolate leaf. Groups of three plants were analyzed at 7,15 , and 40 days postinoculation (dpi). A, Samples were collected at locations corresponding to the inoculated region (1), the adjacent area toward the petiole (2), the petiole of the inoculated leaf (3), and the youngest newly emerged leaf (4). DNA extracted from each sample location was applied (two loadings of 1 and $0.5 \mu 1$ per sample) to positively charged nylon membranes. B, The blot was hybridized with a DNA probe to TYLCV. 
virus induced gene silencing in both genotypes. Moreover, at 14 dpi, more abundant accumulation of TYLCV-specific small RNAs was observed in plants of the susceptible genotype. No TYLCV-specific hybridization was detected from RNA samples isolated from mock-inoculated control plants of either genotype, indicating that inoculated plants responded specifically to the virus.

A single dominant gene confers resistance to TYLCV in GG12. TYLCV-susceptible plants could be distinguished easily from resistant plants by obvious BLCD symptoms at 40 dpi and clear hybridization signals in tissue blot hybridization analysis of newly emerged leaves (Fig. 2A, location 4) at 15 and 40 dpi. No symptoms or hybridization signals were observed for resistant plants. All GG14 plants were susceptible to TYLCV and all GG12 plants were resistant. The response of $F_{1}$ plants was indistinguishable from that of the GG12 parent (Table 4), and the $\mathrm{F}_{2}$ population segregated as approximately three resistant to one susceptible plant. These segregation data are consistent with the
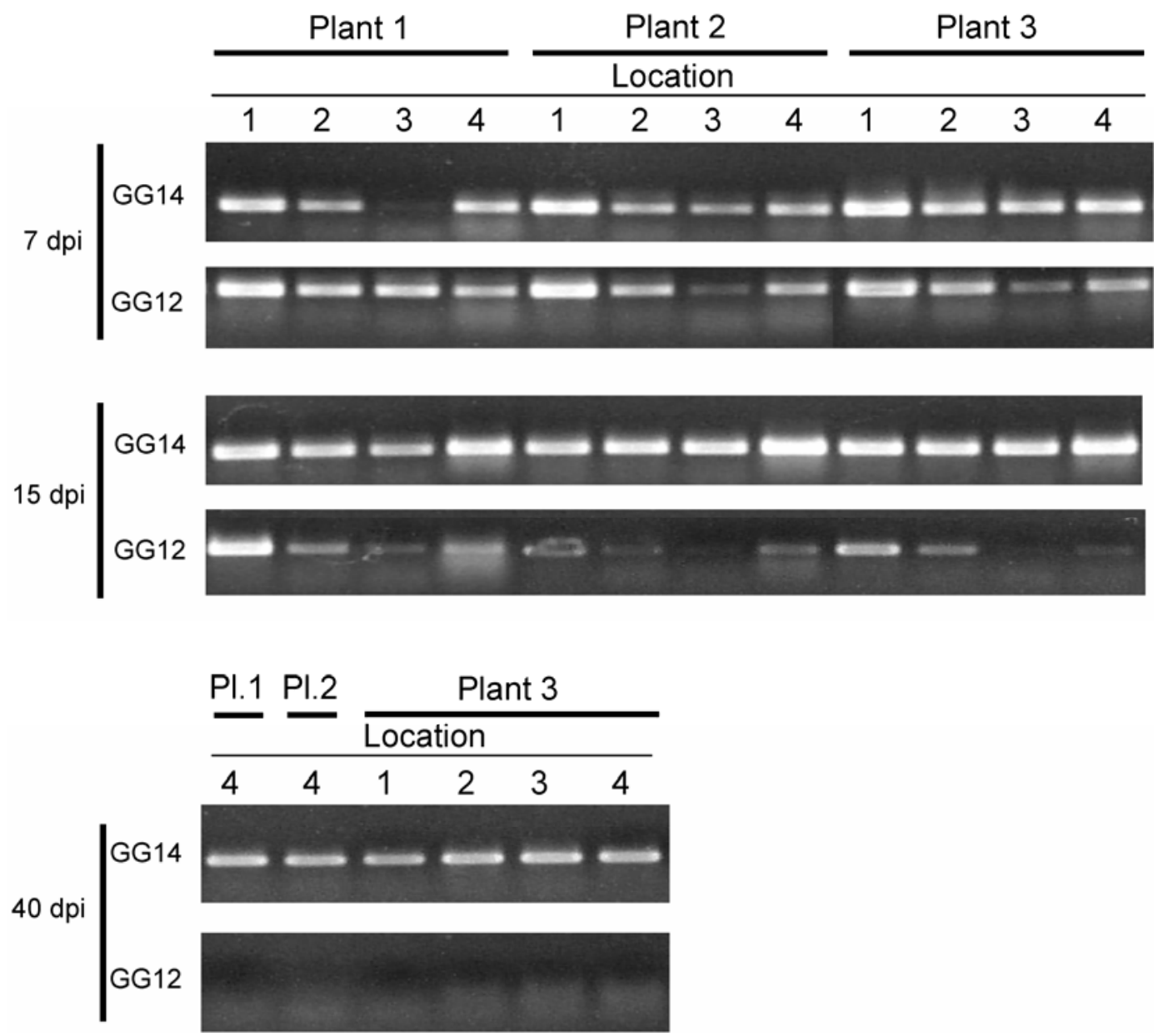

Fig. 3. Polymerase chain reaction (PCR) analysis of Tomato yellow leaf curl virus (TYLCV) distribution in Phaseolus vulgaris GG12 and GG14 agroinoculated with TYLCV-Mld. Inoculum was applied to wounds made in the expanded blade of one leaflet of the first trifoliolate leaf. Groups of three plants were analyzed at 7, 15, and 40 days postinoculation (dpi). Template for PCR was DNA extracted from tissues of locations corresponding to the inoculated region (1), the adjacent area toward the petiole (2), the petiole of the inoculated leaf (3), and the youngest newly emerged leaf (4) (schematically represented in Figure 2A). A primer pair specific to TYLCV-Mld was used in PCR.
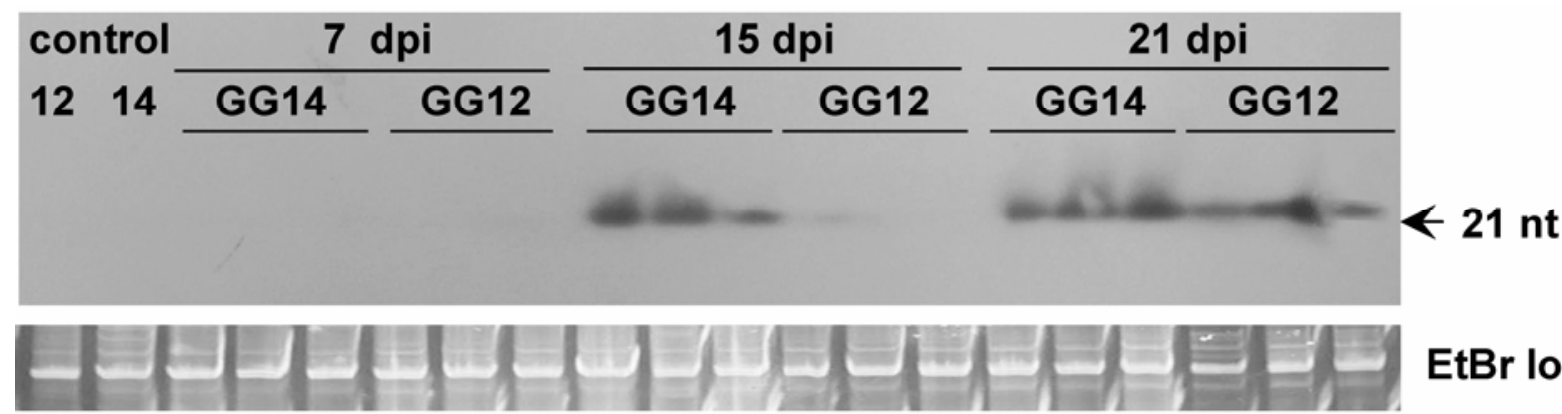

\section{EtBr loading}

Fig. 4. Northern blot hybridization analysis of RNA extracts obtained from newly developed young leaves collected at 7, 15, and 21 days postinoculation (dpi) from GG14 (susceptible) and GG12 (resistant) bean lines. Plants were agroinoculated with the Mld strain of Tomato yellow leaf curl virus (TYLCV-Mld) on the expanded blade of leaflets of the first trifoliolate leaf. Blots were probed with digoxigenin-labeled RNA probes to the complete genome of TYLCV-Mld. Controls are from equivalent samples collected at 21 dpi from GG14 (14) and GG12 (12) mock-inoculated plants. Ethidium bromide (EtBr)-stained RNA is shown as a loading control in the lower panel. The migration of a 21-nucleotide oligonucleotide is indicated on the right. 
hypothesis that a single dominant gene is involved in the BLCD resistance trait present in GG12. This was further supported by data for backcross populations. Thus, all the plants of the backcross $\mathrm{BC}_{1 \mathrm{R}}\left(\mathrm{F}_{1} \times \mathrm{GG} 12\right)$ behaved as resistant, whereas plants of the backcross $\mathrm{BC}_{1 \mathrm{~S}}\left(\mathrm{~F}_{1} \times \mathrm{GG14}\right)$ segregated as approximately one resistant to one susceptible plant (Table 4$)$.

\section{DISCUSSION}

BLCD was first reported from southern Spain in 1997 (40); however, incidence throughout the affected areas was unknown. Field surveys revealed that the disease was widespread and occurred at high incidence in some fields of common bean. The same situation might occur in other bean-growing regions, such as the Caribbean $(33,53)$. Because BLCD can cause serious losses in yield and quality, the availability of BLCD-resistant cultivars is a desirable option. The genetic base of commercial cultivars within a specific market could be relatively narrow (59). Thus, in the BLCD-affected area of southern Spain, large-seeded Andean-type snap beans are mainly used. Presence of disease resistance sources could be explored in distant gene pools, including common bean germ plasm of Middle American origin, which for decades has been a source of disease resistance (and other traits) for snap bean breeding programs $(36,59)$. The basic objective of this study was to identify and characterize sources of resistance to BLCD-associated viruses that may be useful for common bean breeding programs. Resistance in P. vulgaris to TYLCV has been reported recently (26) but inheritance of resistance was not studied. Here, we show that the bean breeding lines GG9 and GG12 exhibited resistance to BLCD under field conditions during two growing seasons in which high disease pressure occurred. Moreover, under experimental conditions, GG12 showed a consistent resistance response to BLCD-associated viruses.

The demonstration that GG12 plants exhibited an equivalent resistance response under either natural (B. tabaci-mediated) or experimental (A. tumefaciens-mediated) inoculations was important. In P. vulgaris, Garrido-Ramírez et al. (19) observed that differences in the resistance response to Bean golden yellow mosaic virus (BGYMV) occurred depending on the inoculation system used. Similarly, during selection of Lycopersicon sp. for resistance to TYLCV, Kheyr-Pour et al. (25) found discrepancies between $B$. tabaci inoculation and agroinoculation. In our case, agroinoculation offered a good alternative to natural inoculation for BLCD-resistance studies involving GG12 and GG14, because our results were similar with both techniques.

Resistance of GG12 was effective against different monopartite begomoviruses associated with BLCD infections: the type and Mld strains of TYLCV $(33,40,41,53)$ and TYLCMalV (35). Therefore, a broad resistance to BLCD-associated viruses may be expected for GG12. This finding is relevant, because usefulness of this resistance gene might be seriously compromised if resistance-breaking virus genotypes already exist $(23,30)$. Durability of the GG12 resistance to TYLCV-like viruses is unknown because evolutionary potential for TYLCV is predicted to be high (18).

Genetic analysis suggested that a single dominant gene conferred resistance in GG12. GG12 is a market-type common bean; therefore, this resistance should be relatively easy to introgress into susceptible cultivars adapted to agronomic and market characteristics of areas affected by BLCD. Dominant inheritance of resistance is common. Fraser (17) showed that approximately half of the resistance traits examined randomly were under this type of genetic control. For example, in tomato, the resistance used most frequently to combat the tomato yellow leaf curl disease caused by monopartite begomoviruses (38) is based on the partially dominant $T y-1$ gene (71). In common bean, a single dominant allele (tentatively designated $B c t$ ) was associated with resistance to the curtovirus (family Geminiviridae) Beet curly top virus (28). The current convention for gene designation is to assign a gene symbol to each host factor that controls the response to a particular virus (47). Nevertheless, we avoided assigning a symbol to the gene conferring resistance to TYLCV in GG12 because linkage with reported genes that confer resistance to other begomoviruses in $P$. vulgaris has not been excluded. Resistance genes to begomoviruses affecting $P$. vulgaris have been described for Bean dwarf mosaic virus (BDMV) or for viruses causing the bean golden mosaic disease (BGMD) $(3,36,58)$. For BDMV, the resistance also was associated with a single dominant gene. In contrast to GG12 resistance against BLCD-causing agents, BDMV never was detected systemically in resistant plants $(58,62,68)$. This suggests that a different resistance trait may be operating in GG12. For the viruses associated with the BGMD (BGYMV and Bean golden mosaic virus [BGMV]) (16,19), moderate resistance was associated with recessive or quantitative trait loci $(6,27,36,60,65)$. The fact that GG12 plants were completely susceptible when challenged with a BGMD-causing virus (J. A. Maldonado, unpublished data) further suggests that resistance to BGMD differs from that to BLCD.

Our results showed that the GG12 resistance trait prevented BLCD-symptom development. Although the virus still could spread systemically, resistance resulted in a dramatic restriction of TYLCV accumulation. The inability to efficiently infect a plant species can be associated with replication deficiencies, as observed for some geminivirus-host interactions $(29,61)$. Nevertheless, early stages of TYLCV infection were not impaired in GG12 plants, and a similar behavior was observed in resistant and susceptible plants. This suggested that resistance might limit TYLCV transport in GG12 plants, similar to that reported in other virusresistance systems for either DNA $(9,68)$ or RNA viruses $(63)$. However, in contrast to the complete block of virus systemic invasion found in BDMV-resistant plants $(58,68)$, our data indicate that TYLCV can move long distance within GG12 plants, albeit less efficiently than in susceptible plants.

TABLE 4. Segregation data for Tomato yellow leaf curl virus (TYLCV) resistance in populations derived from Phaseolus vulgaris GG12 and GG14, and goodness-of-fit/segregation ratio expected from a model in which resistance is controlled by a single dominant gene

\begin{tabular}{|c|c|c|c|c|c|c|}
\hline \multirow[b]{2}{*}{ Populations } & \multicolumn{3}{|c|}{ Number of plants $\mathrm{s}^{\mathrm{a}}$} & \multirow[b]{2}{*}{ Expected ratio } & \multicolumn{2}{|c|}{ Goodness-of-fit } \\
\hline & Total & Resistant & Susceptible & & $\chi^{2}$ & $P$ \\
\hline GG14 & 18 & 0 & 18 & $\ldots$ & $\ldots$ & $\ldots$ \\
\hline GG12 & 17 & 17 & 0 & $\ldots$ & $\ldots$ & $\ldots$ \\
\hline $\mathrm{BC}_{1 \mathrm{R}}\left(\mathrm{F}_{1} \times \mathrm{GG} 12\right)$ & 44 & 44 & 0 & $\ldots$ & $\ldots$ & $\ldots$ \\
\hline $\mathrm{BC}_{1 \mathrm{~S}}\left(\mathrm{~F}_{1} \times \mathrm{GG} 14\right)$ & 36 & 19 & 17 & $1: 1$ & 0.11 & 0.74 \\
\hline$F_{2}$ & 131 & 93 & 38 & $3: 1$ & 1.12 & 0.29 \\
\hline
\end{tabular}

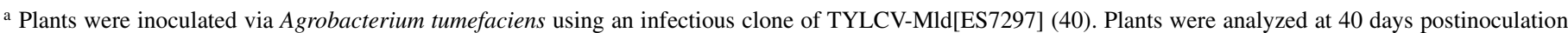
for presence of bean leaf crumple disease (BLCD) by symptom observation, and for presence of virus by hybridization of tissue blots of petiole cross sections of newly emerged young leaves performed on positively-charged nylon membranes. For detection, a probe able to recognize TYLCV (40) was used. Resistant plants showed neither BLCD symptoms nor hybridization signal, whereas susceptible plants exhibited evident BLCD symptoms and hybridization signal. 
Time-course analyses suggested that a recovery from virus infection occurred in GG12 plants, as evidenced by the absence of viral DNA at 40 dpi (Fig. 3). Therefore, a host antiviral defense mechanism may be operating in this resistance system. Natural host recovery from viral disease has been described as a form of host resistance response to plant virus infection $(24,50)$ associated with gene-silencing mechanisms $(10,12,14,48,70)$. In transgenic plants, silencing of viral RNAs can result in reduced virus accumulation in infected plants $(12,21,48,49)$. Begomoviruses can trigger silencing mechanisms and, in certain cases, silencing has been related with recovery from infection $(10,46)$. However, no correlation was found here between resistance and accumulation of TYLCV-specific small RNAs. Nevertheless, it should be noted that other factors not studied here may play a crucial role in the expression of a recovery phenotype $(10,34,48,70)$.

In summary, a resistance trait for BLCD-associated viruses was identified and characterized. This is of particular importance because begomoviruses associated with BLCD are emerging worldwide (38) and can be a serious threat to areas that traditionally grow common bean. The simple genetic control found for this resistance trait may facilitate rapid transfer into commercial cultivars.

\section{ACKNOWLEDGMENTS}

This research was partially funded by grants AGF98-0439-C05-02 (Comisión Interministerial de Ciencia y Tecnología, CICYT, Spain), and AGL2001-1857-C04-02 (CICYT, European Commission). Francisco Monci completed this research as part of his Ph.D. degree and was recipient of an MIT fellowship from the Ministerio de Ciencia y Tecnología, Spain. Susana García-Andrés was recipient of a fellowship from the Ministerio de Educación y Cultura. We thank E. Rybicki, M. A. Aranda, and J. Navas-Castillo for helpful discussion and critical reading of the manuscript; E. Bejarano for providing the infectious clone of TYLCV; M. V. Martín and A. A. Tortosa for technical assistance; E. Rodríguez-Cerezo for providing the cauliflower $18 \mathrm{~S}$ ribosomal RNA gene; R. Fernandez-Muñoz for assistance with genetic analyses; and all the people who helped us during field studies.

\section{LITERATURE CITED}

1. Accotto, G. P., Navas-Castillo, J., Noris, E., Moriones, E., and Louro, D. 2000. Typing of tomato yellow leaf curl viruses in Europe. Eur. J. Plant Pathol. 106:179-186.

2. Antignus, Y., and Cohen, S. 1994. Complete nucleotide sequence of an infectious clone of a mild isolate of Tomato yellow leaf curl virus (TYLCV). Phytopathology 84:707-712.

3. Aragao, F. J. L., Ribeiro, S. G., Barros, L. M. G., Brasileiro, A. C. M., Maxwell, D. P., Rech, E. L., and Faria, J. C. 1998. Transgenic beans (Phaseolus vulgaris L.) engineered to express viral antisense RNAs show delayed and attenuated symptoms to bean golden mosaic geminivirus. Mol. Breed. 4:491-499.

4. Baulcombe, D. 2002. RNA silencing. Curr. Biol. 12:R82-84.

5. Bevan, M. 1984. Binary vectors for plant transformation. Nucleic Acids Res. 12:8711-8721.

6. Bianchini, A. 1999. Resistance to bean golden mosaic virus in bean genotypes. Plant Dis. 83:615-620.

7. Cahill, M., Gorman, K., Day, S., Denholm, J., Elbert, A., and Naven, R., 1996. Baseline determination and detection of resistance to imidacloprid in Bemisia tabaci (Homoptera: Aleyrodidae). Bull. Entomol. Res. 86:343349.

8. Cahill, M., Jarvis, W., Gorman, K., and Denholm, J. 1996. Resolution of baseline responses and documentation of resistance to buprofezin in Bemisia tabaci (Homoptera: Aleyrodidae). Bull. Entomol. Res. 86:117122.

9. Carrington, J. C., Kasschau, K. D., Mahajan, S. K., and Schaad, M. C. 1996. Cell-to-cell and long-distance transport of viruses in plants. Plant Cell 8:1669-1681.

10. Chellappan, P., Vanitharani, R., and Fauquet, C. M. 2004. Short interfering RNA accumulation correlates with host recovery in DNA virusinfected hosts, and gene silencing targets specific viral sequences. J. Virol. 78:7465-7477.

11. Covey, S. N., and Al-Kaff, N. S. 2000. Plant DNA viruses and gene silencing. Plant Mol. Biol. 43:307-322.
12. Covey, S. N., Al-Kaff, N. S., Langara, A., and Turner, D. S. 1997. Plants combat infection by gene silencing. Nature 385:781-782.

13. Cox, K. H., DeLeon, D. V., Angerer, L. M., and Angerer, R. C. 1984 Detection of mRNAs in sea urchin embryos by in situ hybridization using asymmetric RNA probes. Dev. Biol. 101:485-502.

14. Duan, Y. P., Powell, C. A., Webb, S. E., Purcifull, D. E., and Hiebert, E. 1997. Geminivirus resistance in transgenic tobacco expressing mutated BC1 protein. Mol. Plant-Microbe Interact. 10:617-623.

15. Elbert, A., and Nauen, R. 2000. Resistance of Bemisia tabaci (Homoptera: Aleyrodidae) to insecticides in southern Spain with special reference to neonicotinoids. Pest Manage. Sci. 56:60-64.

16. Faria, J. C., and Maxwell, D. P. 1999. Variability in geminivirus isolates associated with Phaseolus spp. in Brazil. Phytopathology 89:262-268.

17. Fraser, R. S. S. 1992. The genetics of plant-virus interactions. Implications for plant-breeding. Euphytica 63:175-185.

18. García-Arenal, F., and McDonald, B. A. 2003. An analysis of the durability of resistance to plant viruses. Phytopathology 93:941-952.

19. Garrido-Ramírez, E. R., Sudarshana, M. R., and Gilbertson, R. L. 2000. Bean golden yellow mosaic virus from Chiapas, Mexico: Characterization, pseudorecombination with other bean-infecting geminiviruses, and germ plasm screening. Phytopathology 90:1224-1232.

20. Goto, K., Kanazawa, A., Kusaba, M., and Masuta, C. 2003. A simple and rapid method to detect plant siRNAs using nonradioactive probes. Plant Mol. Biol. Rep. 21:51-58.

21. Guo, H. S., and García, J. A. 1997. Delayed resistance to plum pox potyvirus mediated by a mutated RNA replicase gene: Involvement of a gene silencing mechanism. Mol. Plant-Microbe Interact. 10:160-170.

22. Hamilton, A., Voinnet, O., Chappell, L., and Baulcombe, D. 2002. Two classes of short interfering RNA in RNA silencing. EMBO J. 21:4671-4679.

23. Harrison, B. D. 2002. Virus variation in relation to resistance-breaking in plants. Euphytica 124:181-192.

24. Hull, R. 2002. Matthews' Plant Virology. 4th ed. Academic Press, San Diego, CA.

25. Kheyr-Pour, A., Grobenborn, B., and Czosnek, H. 1994. Agroinoculation of Tomato yellow leaf curl virus (TYLCV) overcomes the virus resistance of wild Lycopersicon species. Plant Breed. 112:228-233.

26. Lapidot, M. 2002. Screening common bean (Phaseolus vulgaris) for resistance to tomato yellow leaf curl virus. Plant Dis. 86:429-432.

27. Lapidot, M., and Friedmann, M. 2002. Breeding for resistance to whitefly-transmitted geminiviruses. Ann. Appl. Biol. 140:109-127.

28. Larsen, L. C., and Miklas, P. N. 2004. Generation and molecular mapping of a sequence characterized amplified region marker linked with the $B c t$ gene for resistance to Beet curly top virus in common bean. Phytopathology 94:320-325.

29. Lazarowitz, S. G. 1991. Molecular characterization of two bipartite geminiviruses causing squash leaf curl disease: Role of viral replication an movement functions in determining host range. Virology 180:70-80.

30. Lecoq, H., Moury, B., Desbiez, C., Palloix, A., and Pitrat, M. 2004. Durable virus resistance in plants through conventional approaches: A challenge. Virus Res. 100:31-39.

31. Lin, C. S., Poushinsky, G., and Mauer, M. 1979. An examination of five sampling methods under random and clustered distribution using simulation. Can. J. Plant Sci. 59:121-130.

32. Lucioli, A., Noris, E., Brunetti, A., Tavazza, R., Ruzza, V., Castillo, A. G., Bejarano, E. R., Accotto, G. P., and Tavazza, M. 2003. Tomato yellow leaf curl Sardinia virus Rep-derived resistance to homologous and heterologous geminiviruses occurs by different mechanisms and is overcome if virus-mediated transgene silencing is activated. J. Virol. 77:6785-6798.

33. Martínez-Zubiaur, Y., Quiñones, M., Fonseca, D., Potter, J. L., and Maxwell, D. P. 2002. First report of Tomato yellow leaf curl virus associated with beans, Phaseolus vulgaris, in Cuba. Plant Dis. 86:814.

34. Moissiard, G., and Voinnet, O. 2004. Viral suppression of RNA silencing in plants. Mol. Plant Pathol. 5:71-82.

35. Monci, F., Sanchez-Campos, S., Navas-Castillo, J., and Moriones, E. 2002. A natural recombinant between the geminiviruses Tomato yellow leaf curl Sardinia virus and Tomato yellow leaf curl virus exhibits a novel pathogenic phenotype and is becoming prevalent in Spanish populations. Virology 303:317-326.

36. Morales, F. J. 2001. Conventional breeding for resistance to Bemisia tabaci-transmitted geminiviruses. Crop Prot. 20:825-834.

37. Morales, F. J., and Anderson, P. K. 2001. The emergence and dissemination of whitefly-transmitted geminiviruses in Latin America. Brief review. Arch. Virol. 146:415-441.

38. Moriones, E., and Navas-Castillo, J. 2000. Tomato yellow leaf curl virus, an emerging virus complex causing epidemics worldwide. Virus Res. 71:123-134.

39. Muangsan, N., Beclin, C., Vaucheret, H., and Robertson, D. 2004. Geminivirus VIGS of endogenous genes requires SGS2/SDE1 and SGS3 and defines a new branch in the genetic pathway for silencing in plants. Plant J. 38:1004-1014. 
40. Navas-Castillo, J., Sánchez-Campos, S., Díaz, J. A., Saez-Alonso, E., and Moriones, E. 1999. Tomato yellow leaf curl virus-Is causes a novel disease of common bean and severe epidemics in tomato in Spain. Plant Dis. 83:29-32.

41. Navas-Castillo, J., Sánchez-Campos, S., Noris, E., Louro, D., Accotto, G. P., and Moriones, E. 2000. Natural recombination between Tomato yellow leaf curl virus-Is and Tomato leaf curl virus. J. Gen. Virol. 81:2797-2801.

42. Noris, E., Accotto, G. P., Tavazza, R., Brunetti, A., Crespi, S., and Tavazza, M. 1996. Resistance to tomato yellow leaf curl geminivirus in Nicotiana benthamiana plants transformed with a truncated viral $\mathrm{C} 1$ gene. Virology 224:130-138.

43. Noris, E., Hidalgo, E., Accotto, G. P., and Moriones, E. 1994. High similarity among the tomato yellow leaf curl virus isolates from the West Mediterranean Basin: The nucleotide sequence of an infectious clones from Spain. Arch. Virol. 135:165-170.

44. Picó, B., Díez, M. J., and Nuez, F. 1996. Viral diseases causing the greatest economic losses to the tomato crop. 2. The Tomato yellow leaf curl virus-A review. Sci. Hortic. (Amsterdam) 67:151-196.

45. Polston, J. E., and Anderson, P. K. 1997. The emergence of whiteflytransmitted geminiviruses in tomato in the western hemisphere. Plant Dis. 81:1358-1369.

46. Pooggin, M., Shivaprasad, P. V., Veluthambi, K., and Hohn, T. 2003. RNAi targeting of DNA virus in plants. Nat. Biotechnol. 21:131-132.

47. Provvidenti, R., and Hampton, R. O. 1992. Sources of resistance to viruses in the Potyviridae. Arch. Virol. Suppl. 5:189-211.

48. Ratcliff, F. G., MacFarlane, S. A., and Baulcombe, D. C. 1999. Gene silencing without DNA: RNA-mediated cross-protection between viruses. Plant Cell 11:1207-1215.

49. Ruiz, M. T., Voinnet, O., and Baulcombe, D. C. 1998. Initiation and maintenance of virus-induced gene silencing. Plant Cell 10:937-946.

50. Ryang, B. S., Kobori, T., Matsumoto, T., Kosaka, Y., and Ohki, S. T. 2004. Cucumber mosaic virus $2 \mathrm{~b}$ protein compensates for restricted systemic spread of Potato virus $\mathrm{Y}$ in doubly infected tobacco. J. Gen. Virol. 85:3405-3414.

51. Rybicki, E. P., Briddon, R. W., Brown, J. K., Fauquet, C. M., Maxwell, D. P., Stanley, J., Harrison, B. D., Markham, P. G., Bisaro, D. M., and Robinson, D. 2000. Family Geminiviridae. Pages 285-297 in: Virus Taxonomy, 7th Report of the International Committee on Taxonomy of Viruses. M. H. V. Van Regenmortel, C. M. Fauquet, D. H. L. Bishop, E. Carstens, M. K. Estes, S. M. Lemon, J. Maniloff, M. A. Mayo, D. J. McGeoch, C. R. Pringle, and R. B. Wickner, eds. Academic Press, San Diego, CA.

52. Rybicki, E. P., and Pietersen, G. 1999. Plant virus disease problems in the developing world. Adv. Virus Res. 53:127-175.

53. Salati, R., Nahkla, M. K., Rojas, M. R., Guzman, P., Jaquez, J., Maxwell, D. P., and Gilbertson, R. L. 2002. Tomato yellow leaf curl virus in the Dominican Republic: Characterization of an infectious clone, virus monitoring in whiteflies, and identification of reservoir hosts. Phytopathology 92:487-496.

54. Sambrook, J., Fritsch, E. F., and Maniatis, T. A. 1989. Molecular Cloning: A Laboratory Manual. 2nd ed. Cold Spring Harbor Laboratory, Cold Spring Harbor, NY.
55. Sánchez-Campos, S., Navas-Castillo, J., Camero, R., Soria, C., Díaz, J. A., and Moriones, E. 1999. Displacement of tomato yellow leaf curl virus (TYLCV)-Sr by TYLCV-Is in tomato epidemics in Spain. Phytopathology 89:1038-1043.

56. Segundo, E., Martín, I. M., Cuadrado, I. M., and Janssen, D. 2004. A new yellowing disease in Phaseolus vulgaris associated with a whiteflytransmitted virus. Plant Pathol. 53:517.

57. Selth, L. A., Randles, J. W., and Rezaian, M. A. 2002. Agrobacterium tumefaciens supports DNA replication of diverse geminivirus types. FEBS Lett. 516:179-182.

58. Seo, Y. S., Gepts, P., and Gilbertson, R. L. 2004. Genetics of resistance to the geminivirus, Bean dwarf mosaic virus, and the role of the hypersensitive response in common bean. Theor. Appl. Genet. 108:786-793.

59. Singh, S. P. 2001. Broadening the genetic base of common bean cultivars: A review. Crop Sci. 41:1659-1675.

60. Singh, S. P., Morales, F. J., Miklas, P. N., and Teran, H. 2000. Selection for bean golden mosaic resistance in intra- and interracial bean populations. Crop Sci. 40:1565-1572.

61. Stenger, D. C., Davis, K. R., and Bisaro, D. M. 1992. Limited replication of Tomato golden mosaic virus DNA in explants of nonhost species. Mol. Plant-Microbe Interact. 5:525-527.

62. Sudarshana, M. R., Wang, H. L., Lucas, W. J., and Gilbertson, R. L. 1998 Dynamics of bean dwarf mosaic geminivirus cell-to-cell and longdistance movement in Phaseolus vulgaris revealed, using the green fluorescent protein. Mol. Plant-Microbe Interact. 11:277-291.

63. Valkonen, J. P. T., and Somersalo, S. 1996. Patterns and barriers of cellto-cell movement and lack of systemic spread of tobacco etch potyvirus (TEV-GUS) in Solanum brevidens. Plant Sci. 113:221-228.

64. Vance, V., and Vaucheret, H. 2001. RNA silencing in plants-Defense and counterdefense. Science 292:2277-2280.

65. Velez, J. J., Bassett, M. J., Beaver, J. S., and Molina, A. 1998. Inheritance of resistance to bean golden mosaic virus in common bean. J. Am. Soc. Hortic. Sci. 123:628-631.

66. Verhoeven, J. T. J., Roenhorst, J. W., Lesemann, D. E., Segundo, E., Velasco, L., Ruiz, L., Janssen, D., and Cuadrado, I. M. 2003. Southern bean mosaic virus the causal agent of a new disease of Phaseolus vulgaris beans in Spain. Eur. J. Plant Pathol. 109:935-941.

67. Voinnet, O. 2001. RNA silencing as a plant immune system against viruses. Trends Genet. 17:449-459.

68. Wang, H. L., Sudarshana, M. R., Gilbertson, R. L., and Lucas, W. J. 1999. Analysis of cell-to-cell and long-distance movement of a bean dwarf mosaic geminivirus-green fluorescent protein reporter in host and nonhost species: Identification of sites of resistance. Mol. Plant-Microbe Interact. $12: 345-355$.

69. Waterhouse, P. M., Wang, M. B., and Lough, T. 2001. Gene silencing as an adaptive defence against viruses. Nature 411:834-842.

70. Xin, H. W., and Ding, S. W. 2003. Identification and molecular characterization of a naturally occurring RNA virus mutant defective in the initiation of host recovery. Virology 317:253-262.

71. Zamir, D., Eksteinmichelson, I., Zakay, Y., Navot, N., Zeidan, M., Sarfatti, M., Eshed, Y., Harel, E., Pleban, T., Vanoss, H., Kedar, N., Rabinowitch, H. D., and Czosnek, H. 1994. Mapping and introgression of a Tomato yellow leaf curl virus tolerance gene, Ty-1. Theor. Appl. Genet. 88:141-146. 